\title{
The Cronkhite-Canada syndrome: an ultrastructural study of pathogenesis
}

\author{
D JENKINS, PM STEPHENSON, BB SCOTT \\ From the Departments of Pathology and Medicine, Lincoln County Hospital, Lincoln
}

SUMMARY Electron microscopical and cytochemical studies of intestinal biopsies from a patient with typical features of the Cronkhite-Canada syndrome show that the primary process affects the crypts. This results in cystic dilatation associated with expansion and focal degeneration of the crypt compartment of the intestinal epithelium. The villous epithelium compartment is reduced but ultrastructurally normal. Inflammation and oedema of the lamina propria follows from leakage of mucin through breaks in the abnormal crypts.

The syndrome of gastrointestinal polyposis, alopecia, and nail dystrophy now known as the Cronkhite-Canada syndrome was first described in 1955.' Although about 80 cases have now been reported there is little information about the aetiology and pathogenesis. The main clinical effects of the gastrointestinal disease are protein losing enteropathy, hypoproteinaemia, and a range of abnormalities in the absorption of carbohydrates, proteins, and fats. ${ }^{23}$ Radioisotope and scanning electron microscopical studies have suggested that the protein loss results from heavy secretion of mucous substances containing protein rather than exudation or rupture of vessels. ${ }^{3}$ Acquired disaccharidase deficiency and intestinal bacterial overgrowth have been shown in a few cases. There is no familial pattern of incidence. Remission may occur, ${ }^{4}$ either spontaneously or after partial surgical resection, corticosteroid treatment, or nutritional support. Surprisingly, there are no detailed descriptions of the transmission electron microscopical appearances of the gastrointestinal lesions. We describe the electron microscopy and cytochemistry of a typical case.

\section{Case report}

A 66 year old man presented with a four month history of scalp hair loss; a three month history of diarrhoea, abdominal pain, and weight loss; and loose nails and ankle swelling for two weeks. Results of investigations were as follows. Haemoglobin concentration $13.4 \mathrm{~g} / \mathrm{dl}$; blood film was normal; ery-

Accepted for publication 30 October 1984 throcyte sedimentation rate $55 \mathrm{~mm}$ in the first hour; serum $B_{12}$ and folate were normal; prothrombin time was normal; serum albumin $33 \mathrm{~g} / \mathrm{l}$; serum alkaline phosphatase 299 units (normal less than 250); serum calcium $1.88 \mathrm{mmol} / \mathrm{l}$; faecal fat 41 $\mathrm{mmol} / 24 \mathrm{~h}$. A lactose tolerance test using breath hydrogen was normal; small bowel enema suggested malabsorption; sigmoidoscopy showed a normal mucosa; upper gastrointestinal endoscopy showed a strikingly polypoid antrum, pylorus, and duodenum.

$\mathrm{He}$ was given only calciferol and folic acid and spontaneously improved over the next six months. He regained his weight, his diarrhoea ceased, his scalp hair regrew, but his nails remained dystrophic.

\section{METHODS}

\section{Light microscopy}

Endoscopic biopsies were obtained from the stomach, duodenum, and rectum. Sections of formalin fixed, paraffin embedded tissue were stained with haematoxylin and eosin, by the periodic acid Schiff (PAS) method with and without diastase digestion, by Hale's dialysed iron technique, with Alcian blue at $\mathrm{pH} 2.5$ and 1.0 and after sialidase treatment by the high iron diamine technique, and by the combined high temperature methylation saponification technique. ${ }^{5}$ Sections were also stained for IgA, IgM, IgG, IgE, and muramidase by the peroxidaseantiperoxidase immunoperoxidase technique. ${ }^{\circ}$

\section{Electron microscopy}

Some endoscopic biopsies of polypoid mucosa from the duodenum were orientated, processed through glutaraldehyde fixation and postfixation in osmium 
tetroxide, and stained with uranyl acetate before embedding in Araldite.? Semithin sections were stained with haematoxylin and eosin ${ }^{8}$ for light microscopy, and ultrathin sections from blocks showing no evidence of biopsy trauma were further stained with lead citrate and examined in a JEOL $100 \mathrm{~S}$ transmission electron microscope. Specimens for ultrastructural cytochemistry were fixed in paraformaldehyde and embedded in Araldite resin. Ultrathin sections were stained by the periodic acid thiocarbohydrazide silver proteinate (PATSP) method. ${ }^{9}$

\section{Results}

\section{LIGHT MICROSCOPY}

Stereomicroscopical examination of duodenal mucosa showed some normal villi but also flat areas with prominent crypt openings. In sections (Fig. 1) there was patchy partial villous atrophy with elongated and irregular crypts and glandular cysts. The dilated crypts and cysts were lined by columnar epithelium and contained mucin, granular debris, degenerate epithelial cells, and foamy histiocytes. Extensive areas of the epithelium were pale staining, attenuated, and flattened. In places the attenuated epithelium was lost exposing the lamina propria, which showed oedema and was infiltrated by many histiocytes and some plasma cells and eosinophils. Biopsies from the gastric antrum showed that the

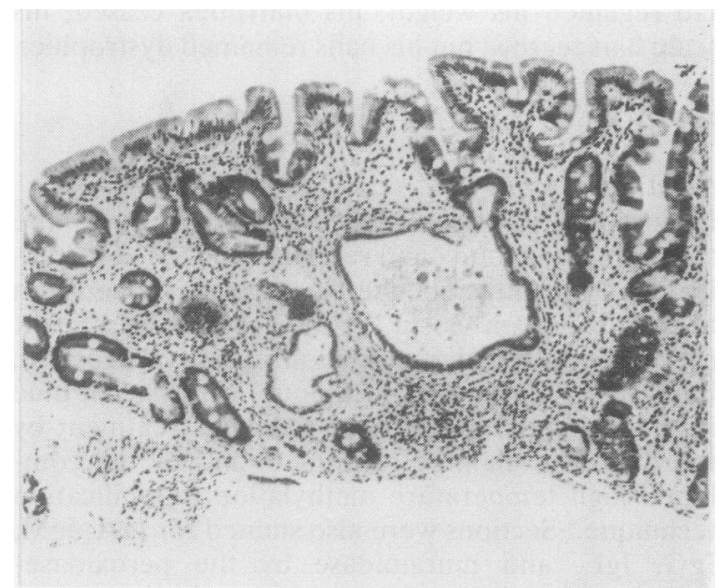

Fig. 1 Light micrograph of duodenal mucosa in Cronkhite-Canada syndrome. There is irregular partial villous atrophy, with elongated, irregular, and cystic crypts. The cysts are lined by attenuated epithelium. There is a mixed inflammatory cell infiltrate in the lamina propria. Haematoxylin and eosin. Original magnification $\times 125$. pits and mucous glands were irregular, branched, and often cystic. The rectal mucosa showed slight irregularity and dilatation of the crypts.

Abundant PAS positive mucinous material was found within intestinal goblet cells and gastric mucous cells and within the dilated crypts and cysts in intestinal and gastric mucosa. PAS positive material extended across breaches in the epithelium into the lamina propria and was also present in the cytoplasm of histiocytes surrounding such areas. No significant qualitative histochemical abnormality of mucin was detected compared with controls. Immunohistochemical staining for muramidase showed a few Paneth cells at the bases of smallintestinal crypts. The counts of IgA, IgM, IgG, and IgE plasma cells were within normal limits.

\section{Electron microscopy}

The villi and the polypoid areas in the duodenal mucosa were covered by columnar absorptive

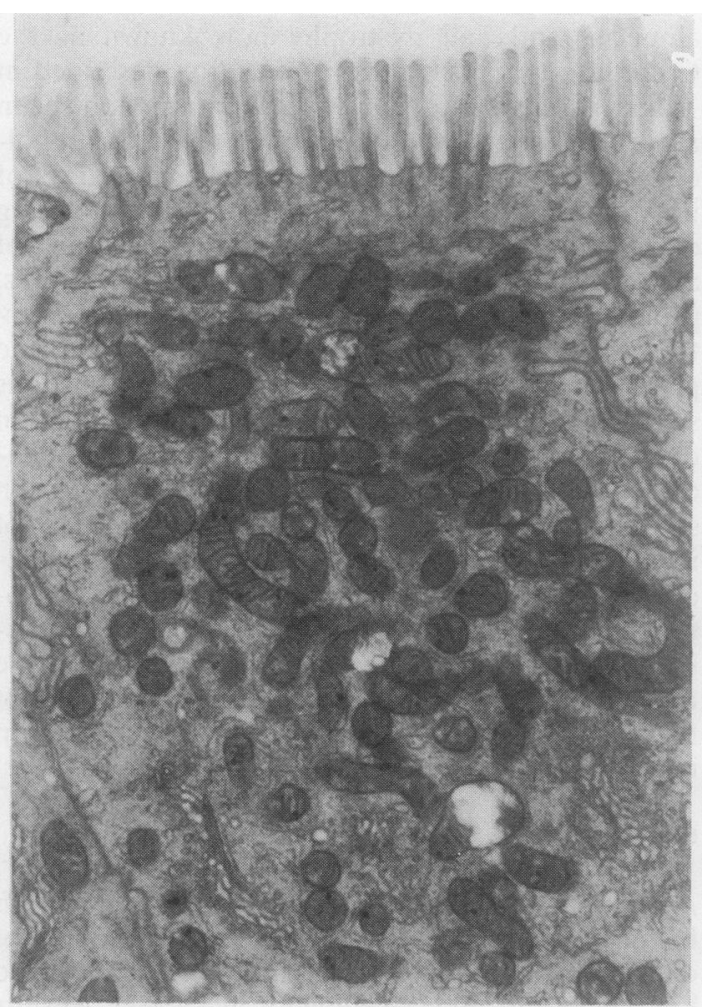

Fig. 2 Electron micrograph of apical part of villous absorptive cell from the surface of the duodenum in Cronkhite-Canada syndrome. Microvilli, lysosomes, endoplasmic reticulum, mitochondria, and intercellular junctions show no pathological changes. Lead citrate and uranyl acetate. Original magnification $\times 12500$. 
epithelium (Fig. 2). The cells appeared normal and showed no abnormalities of microvilli or lysosomes or other degenerative changes. The predominant cell type lining both crypts and the cysts was the undifferentiated crypt cell (Figs. 3 and 4). In crypts and most parts of the cyst walls these cells were columnar with basal nuclei. Round, membrane bound granules up to $1.5 \mu \mathrm{m}$ across were identified in the apical regions of otherwise undifferentiated cells. The PATSP method strongly stained glycoprotein in the glycocalyx on the apical surface, as a rim in the granules, and in the Golgi cisternae. Goblet cells were widespread among the undifferentiated cells as in the lateral walls of normal crypts. Paneth cells were not seen in the walls of cysts, but they were present in the bases of the less abnormal crypts and showed the characteristic large, membrane bound secretory granules in the cytoplasm towards the apex of the cell. Endocrine cells (Fig. 5) were present as in normal small intestinal mucosa.
Throughout the lining of the cysts and crypts small groups of cells or single cells showed degenerative changes with vacuolation and florid dilatation of the endoplasmic reticulum and mitochondria. In some cells the changes amounted to focal necrosis with, in addition, loss of cytoplasmic ground substance and empty nuclei. In some areas dilatation of endoplasmic reticulum and vacuolation were associated with separation of the cells from the basement membrane and from each other, and luminal contents were seen beneath the epithelium (Fig. 5). The underlying basement membrane appeared attenuated. In the adjacent lamina propria there was pronounced oedema with collagen fibres separated by abundant pale staining amorphous material (Fig. 3). Numerous histiocytes, many with large cytoplasmic vacuoles containing amorphous light staining material, were present (Figs. 4 and 5). This material stained black with PATSP, which confirms that these cells were muciphages. Lymphocytes,

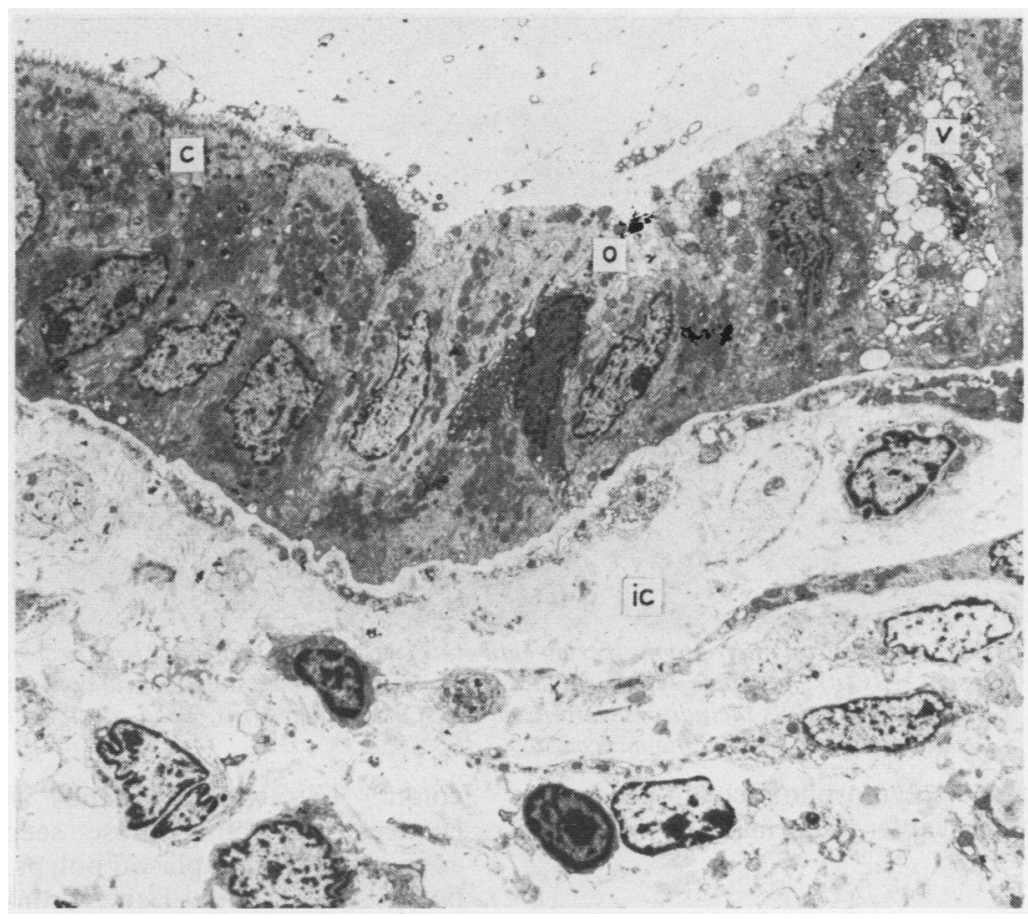

Fig. 3 Electron micrograph of cells lining a cyst and the underlying lamina propria from the duodenum in Cronkhite-Canada syndrome. Most of the cells are undifferentiated crypt cells (c). An oligomucous cell is also present (o). A cell shows vacuolar degeneration (v). The lamina propria shows abundant lightly staining intercellular material (ic). Lead citrate and uranyl acetate. Original magnification $\times 2400$. 


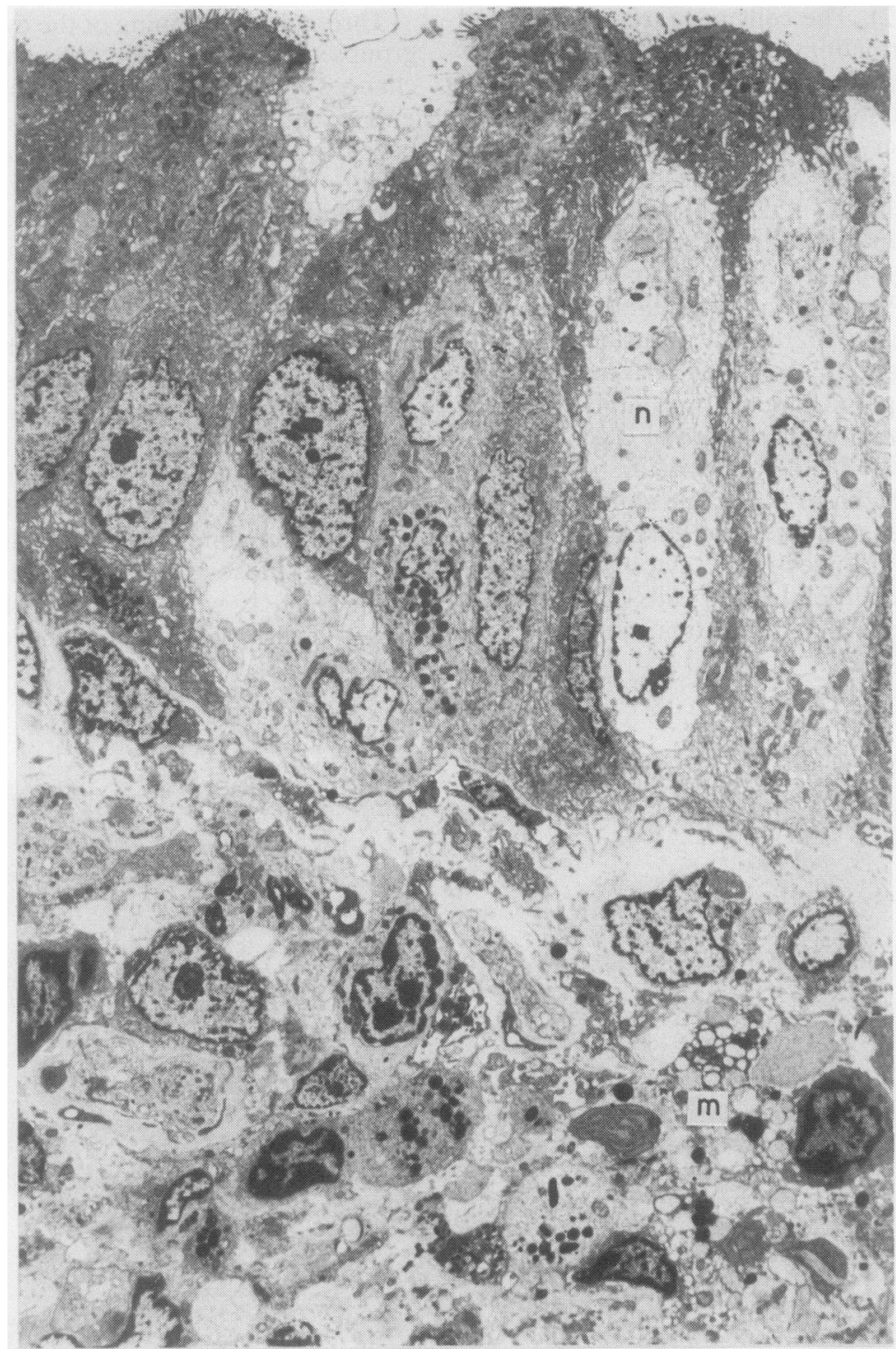

Fig. 4 Electron micrograph of crypt epithelium and lamina propria. Three necrotic crypt cells $(n)$ show pale cytoplasm and empty nuclei. The lamina propria contains inflammatory cells including several vacuolated muciphages $(m)$. Lead citrate and uranyl acetate. Original magnification $\times 2400$.

eosinophils, and polymorphonuclear leucocytes showing no appreciable abnormalities were also seen.

\section{Discussion}

In the initial description the gastrointestinal lesions were said to be adenomatous polyps, but in most recent reports they are described as inflammatory pseudopolyps $^{4}$ resembling juvenile polyps of the colon. ${ }^{10}$ Ultrastructural study shows no epithelial changes resembling those seen in large bowel adenomas or metaplastic polyps. ${ }^{11}$ Unlike juvenile polyps the lesions of the Cronkhite-Canada syndrome are small and diffuse. They do not usually show surface ulceration, blockage of the necks of crypts by inflammation, or qualitative histochemical abnormalities of mucin pattern which are typical of juvenile polyps, ${ }^{12}$ although an occasional case may show extensive ulceration of numerous polyps $(\mathrm{H}$ 


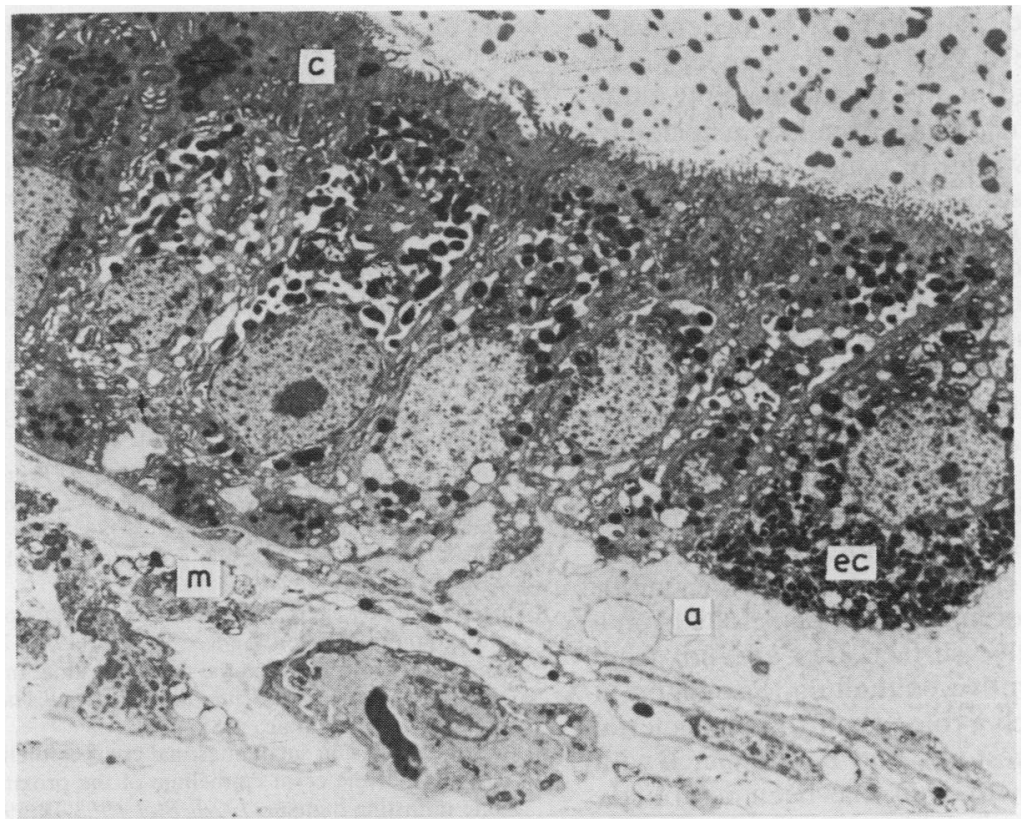

Fig. 5 Electron micrograph of cyst wall. Undifferentiated crypt cells $(c)$ and an enterochromaffin cell (ec) show vacuolation and dilatation of endoplasmic reticulum. Part of the epithelium is separated from the basement membrane by amorphous material $(a)$. Vacuolated muciphages $(m)$ are present in the underlying lamina propria. Lead citrate and uranyl acetate. Original magnification $\times 2500$.

Thompson, personal communication). It has been suggested that juvenile polyps result from epithelial regeneration in granulation tissue following local inflammation and ulceration..$^{12-14}$ This explanation appears inappropriate for the Cronkhite-Canada syndrome, however, because of the structural and histochemical differences from juvenile polyps listed above.

The distinctive structural features of the polypoid lesions of the Cronkhite-Canada syndrome as studied here in the small intestine have to be interpreted in relation to the functional anatomy of the mucosa. The small-intestinal epithelium can be divided into two functionally and structurally distinct compartments: the crypt and the villus. In the Cronkhite-Canada mucosa the villous compartment is reduced, which results in patchy villous atrophy, but the cells appear structurally normal. This is unlike coeliac disease and many diseases associated with malabsorption, in which the villous absorptive cells show striking ultrastructural abnormalities. ${ }^{15}$ The crypt compartment is considerably expanded with elongated, irregular, and cystic crypts lined mostly by undifferentiated crypt cells which are ultrastructurally normal. ${ }^{16}$ These and the goblet cells which they produce ${ }^{17}$ have a physiological function of secreting mucin, ${ }^{18}$ ions, and water. Ultra- cytochemical study shows that mucin production is preserved in the Cronkhite-Canada mucosa. The cystic change is unlikely to result solely from excess mucin production; even massive stimulation of mucin release such as accompanies acetylcholine stimulation does not result in cystic alteration to the crypts of normal small-intestinal mucosa. ${ }^{19} \mathrm{~A}$ previous scanning electron microscopical study reported horn like plugs of highly viscous mucus protruding from crypts. ${ }^{3}$ Our studies do not support the suggestion that an abnormally viscous mucus is involved. The mucin is histochemically normal and the lesions do not show the wide necked open crypts plugged by mucus and the distortion of villi which are known to result from production of viscous mucin in cystic fibrosis. ${ }^{20}$

The reduced but ultrastructurally normal villous compartment and expanded crypt compartment suggest a block in the normal maturation of undifferentiated crypt cells to villous epithelial cells. The degeneration and detachment of lining cells in the abnormal crypts and cysts may indicate selective damage to crypt epithelium by an exogenous agent, as has been shown in vitro to result from bathing the serosal surface of ileal mucosal sheets with solutions depleted of calcium. ${ }^{21}$ Alternatively, the epithelial degeneration may result simply from pressure on the 
wall of distended and cystic crypts. The oedema and inflammation in the lamina propria appear to be secondary to leakage of mucin and possibly other secretions through the damaged wall, as reflected by the muciphages shown in this study.

The remission of some cases ${ }^{4}$ supports the possibility that an exogenous agent or nutritional deficiency might be responsible. No infectious agent was found in this or any other case. ${ }^{22}$ The lesions have been compared to the cystic lesions described in the colons of patients with pellagra, ${ }^{23}$ but cystic changes have not been described elsewhere in the gut in pellagra. The relation of those lesions to CronkhiteCanada syndrome is doubtful.

Ultrastructural study provides further evidence that the characteristic protein loss is due to excess mucus secretion by crypt cells and that the minor and variable degree of malabsorption results from a reduction in absorptive surface area and not from damage to the absorptive epithelium. Reduction in Paneth cells, for which a role in controlling bacterial growth has been suggested, ${ }^{10}$ may be connected with the bacterial overgrowth which has been described.

We thank Dr E Jackson for permission to study this case and the staff of the histopathology and photographic departments of the Lincoln Hospitals. We also thank Mrs A Goodall for her assistance in preparing the paper.

\section{References}

' Cronkhite LW, Canada WJ. Generalised gastrointestinal polyposis. An unusual syndrome of polyposis, pigmentation, alopecia and onychotrophia. N Engl J Med 1955;252:1011-5.

2 Johnston GK, Soergel KH, Hensley GT, Dodds WJ. Cronkhite-Canada syndrome; gastrointestinal pathophysiology and morphology. Gastroenterology 1972;63:140-52.

${ }^{3}$ Suzuki K, Uracka M, Funatsu T, et al. Cronkhite-Canada syndrome. A case report and analytical review of 23 other cases reported in Japan. Gastroenterol J 1979; 14:441-9.

4 Russell DMcR, Bhathall PS, St John DJB. Complete remission in Cronkhite-Canada syndrome. Gastroenterology 1983;85: 180-5.

, Cook HC. Carbohydrates. In: Bancroft JD, Stevens A, eds. Theory and practice of histological technique. London: Churchill-Livingstone, 1977:141-67.
- Scott BB, Goodall A, Stephenson PM, Jenkins D. Small intestinal plasma cells in coeliac disease. Gut 1984;25:41-6.

' Stephenson PM, Jenkins D, Scott BB. Collection and orientation of gastric and intestinal biopsies for combined light and electron microscropy. Med Lab Sci 1983;40:395-6.

${ }^{8}$ Johnson CI, Martinello P, Collier F. Haematoxylin and eosin staining of osmium-fixed tissue in epoxy sections. Med Lab Sci 1982;39:371-5.

9 Thiéry JP. Mise en évidence des polysaccharides sur coupes fines en microscopie électronique.J Microscopie 1967;6:987-1018.

${ }^{10}$ Ruymann FB. Juvenile polyps with cachexia. Gastroenterology 1969;57:431-8.

" Kaye GI, Fenoglio CM, Pascal RR, Lane N. Comparative electron microscopic features of normal, hyperplastic, and adenomatous human colonic epithelium. Gastroenterology 1973;64:926-45.

12 Franzin G, Zamboni G, Dina R, Scarpa A, Fratton A. Juvenile and inflammatory polyps of the colon-a histological and histochemical study. Histopathology 1983;7:719-28.

${ }^{13}$ Roth SI, Helwig EB. Juvenile polyps of the colon and rectum. Cancer 1963;16:468-79.

14 Horrileno EG, Eckert C, Ackermann LV. Polyps of the rectum and colon in children. Cancer 1957;10:1210-20.

is Henry K. Ultrastructure of the small intestine. In: Chadwick VS, Philips SF, eds. Gastroenterology 2. Small intestine. London: Butterworth Scientific, 1982:19-39.

16 Trier JS. Studies on small intestinal crypt epithelium. I. The fine structure of the crypt epithelium of the proximal small intestine of fasting humans. J Cell Biol 1963;18:599-620.

${ }^{17}$ Merzel J, Leblond ÇP. Origin and renewal of goblet cells in the epithelium of mouse small intestine. Am J Anat 1969; 124:281-306.

18 Trier JS. Studies on small intestinal crypt epithelium II. Evidence for and mechanisms of secretory activity by undifferentiated crypt cells of the human small intestine. Gastroenterology 1964;47:480-95.

19 Specian RD. Neutra MR. Mechanism of rapid mucus secretion in goblet cells stimulated by acetylcholine. J Cell Biol 1980;85:626-40.

${ }^{20}$ Jeffrey I, Durrans D, Wells M, Fox $H$. The pathology of meconium ileus equivalent. J Clin Pathol 1983;36:1292-7.

${ }^{21}$ Danowitz M, Madara JL. Effect of extracellular calcium depletion on epithelial structure and function in rabbit ileum; a model for selective crypt of villus epithelial cell damage and suggestion of secretion by villus epithelial cells. Gastroenterology 1982;83:1231-43.

${ }^{22}$ Ali M, Weinstein J, Biempica A, et al. Cronkhite-Canada syndrome; report of a case with bacteriologic, immunologic, and electron microscopic studies. Gastroenterology 1980;79:7316.

${ }^{23}$ Denton J. The pathology of pellagra. Am J Trop Med 1925;5: 173-210.

Requests for reprints to: Dr David Jenkins, Department of Histopathology, Lincoln County Hospital, Lincoln, England. 